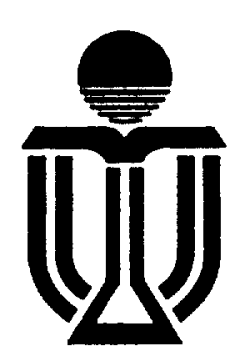

Division of Social Science

The Hong Kong University of Science and Technology

Working Papers in the Social Sciences, No. 40

\title{
Engineering Consultancy: \\ An Assessment of IT-Enabled \\ International Delivery of Services
}

by

Erik Baark

Division of Social Science

Hong Kong University of Science and Technology

Clear Water Bay

Kowloon, Hong Kong

27 July 1998 
Engineering Consultancy: An Assessment of IT-Enabled International Delivery of Services

By Erik Baark

1. Engineering Services: A new process of globalization?

Globalization has been a prevailing trend among manufacturing industries for several decades, affecting the international division of labour in many sectors and ushering in a new category of transnational corporations which increasingly aim to cover global markets on the basis of a network structure rather than a national basis. ${ }^{1}$ Many firms in the service sector, however, have tended to serve local or national markets and it is only recently that a similar tendency of globalization has become apparent in the services." Economic and organizational aspects of the development of transnational service corporations have been rather unique, and many service firms have been less dependent than goods-producing firms on access to global markets since economies of scale have traditionally been less

1. For a pertinent survey of these globalization tre ids and their effects, see UNCTAD, World Investment Report (New York and Geneva: United Nations, 1996), in particular p. 3-28

2. For a collection of papers addressing this change, see Yair Aharoni (ed.) Coalitions and Competition. The Globalization of Prcfessional Business Senices (London and New York: Routledge 1993) 
critical for competitiveness. In addition, opportunities for exploiting comparative advantages through intra-firm specialization have hardly existed for services due to the fact that services often have had to be produced in the same location where they are consumed. Therefore, professional services have generally been delivered by moving the service provider to the location of the customer, often being subject to national regulation and personal interaction between the provider and the client. $^{3}$

Internationalization in the professional service industry has therefore primarily been achieved via two different strategies: client following or market seeking." Engineering consultancy firms have exported services in conjunction with activities of home country clients that were catrying out projects abroad. Here the incentive to follow major domestic clients abroad has provided a natural path to undertaking trade in services; many engineering consultancy firms have longstanding connections with major international contractors and have expanded their

3. These are also the terms in which the Ui uguay Round negotiations of the General Agreement on Trade in Services (GATS) were conducted, and subsequently have been the starting point for similar discussions within the framework of the World Trade Organization.

4. See M.K. Erramilli and C.P. Rao. "Choice of foreign entry modes by service firms: role of market knowledge" Management International Re's iew 30 (1990) p. 135-150 and John H. Dunning, "The Internationalization of the production of services: some general and specific explanations" in Yair Aharoni (ed.) Coalitions and Competition. The Globalization of Professional Business Services (London and New York: Routledge 1993) pp. 79-101, farticularly p. 88. 
overseas activities partly on the basis of such client relationships. ${ }^{5}$ The client following patterns of international transactions in engineering services were thus dominant in the early phases of expansion overseas. This was the case, for instance, when transnational corporations in the petroleum industries expanded their production activities in the Middle Eas:, and engineering consultants serving these corporations established offices or affiliates in the region. In a subsequent phase witnessing the rise of petroleum industries under national ownership in the Middle Eastern countries, the engineering consultants were able to use local affiliates to exploit the market that emerged locally. More recently Japanese engineering consultancy firms have engaged in overseas markets primarily as suppliers of services to Japanese corporations. ${ }^{6}$

Another important pattern of client following behaviour for engineering consultancy firms in several countries has been to provide service for projects undertaken in developing countries by national or international development assistance agencies. The procurement of ençineering consultancy services by development agencies in Scandinavian countries has, for example, been identified

5. See UNCTAD, Information Teihnology and International Competitiveness: The Case of the Construction Services Industry UNCT AD/ITD/TEC/6 (New York: United Nations, 1993), pp. 143182.

6. The dependency of Japanese engineering consultincy firms on Japanese clients for work undertaken abroad is pointed out in both P.J. Rimmer, "The internationalızation of engineering consultancies: problems of breaking into the club" Environment and Planning A Vol. 20 (1988), p. 761-788, and in 
as a key factor in the growth and international competitiveness of engineering consultancy.' Sometimes, the entry or expansion of engineering consultancy firms in international markets has also represented a strategic effort to compensate for stagnating or declining markets at home. ${ }^{8}$ During the early 1990s, this factor has been important for many firms offering services to the building construction industry, which was characterized by stagnation in the US and Europe but was experiencing growth in some newly industrialized developing countries.

Since the early 1980s, however, engineering consultancy firms from industrialized countries have increasingly adopted market secking strategies, seeking to expand their business in markets such as the fast-growing economies of East and Southeast Asia, where domestic supply of services failed to satisfy a growing and more sophisticated demand. These markets were driven by both domestic capital

Peter Enderwick, "The International Competitiveness of Japanese Service Industries: A cause for Concern?" California Management Review (Summer 1990), p. 22-37.

7. This has been the case, in particular, in Denmark and Sweden. See Kim Møller, Videnstjenester $i$ Samfunds $\wp$ konomien (Knowledge services in the national economy) (Copenhagen: Foreningen af Rådgivende Ingeniører, April 1994). p. 38. An earlier study by Henrik Schaumburg-Müller and Bodil Kühn, "Rådgrivende ingeniørvirksombed" in Kim Møller and Henrik Pade (red) Industriel Succes: Konkurencefaktorer i 9 danske brancher |Industrial Success: Factors of Competitiveness in 9 Danish Sectors] (Copenhagen: Samfundslitteratur. 1988) also argued that Danish firms had obtained crucial international experience through work for the development aid agency.

8. It has been suggested that the growth of the domestic markets for engineering design services in the US during the 1980s could have had a detrimential influence on the international market share held by US "pure design" firms. The statistics avallable from EVR - which have changed coverage several times during the decade - does not lend itself to substantiate th is hypothesis. See John A. Stanbury An Exploratory Study of the International Consulting Engineering Design Services Industry: A U.S. Perspective Unpublished Ph.D. Thesis. The Ohio State University (Ann Arbor, Michigan: UMI Dissertation Information Service 1992). 
investment and by the influx of foreign investment. With gradual liberalization of national and international regulation related to services under the new regime of the General Agreement on Trade in Services implemented by the World Trade Organization (WTO), the general anticipation is that regional markets will become more accessible to international engineering consultancy firms. An assessment of the 1996 markets for major US design firms indicated that international work is no longer merely a supplement for business in the domestic market, but has become a substantial and indispensable portion of their practices. ${ }^{9}$ The expansion of engineering consultancy business into the international sphere or global markets raises new questions and presents important pitfalls for many firms. Many US firms have experienced very significant problems with their choice of co-operation partner or the particular format of partnering or investing in overseas countries. ${ }^{10}$

One of the most significant processes of change affecting the internationalization of engineering consultancy service is associated with the diffusion of advanced information and telecommunications technologies. The use of software for computer-aided design has now become ubicuitous in the engineering consultancy sector, and the potential of advanced data communications will facilitate delivery of engineering services across long distances - reducing the need for local

9. See "International Design Work Goe's from 'Mayte' to Mainstay" ENR Vol. 288. No. 15 (April 14). 1977, p. 97. 
presence. This phenomenon gives rise to increased tradability of services, i.e., a technical potential for firms to trade their services directly with foreign clients, without foreign direct investment (FDI) and thus sales conducted by local affiliates. $^{11}$

From the point of view of engineering consultancy firms, however, the technical feasibility of IT-enabled delivery will be only one consideration in formulating strategies to acquire or maintain competitive strategies in international markets. The actual choice of business strategy will be dependent on other considerations such as existing regulations at the national and international level, the demands for local representation at the project site or in the vicinity of the client's office, and the economic feasibility of IT-enabled delivery. The economic and political environments in which the engineering consulting industry is operating naturally influence the ways in which this potential is realised. In an industry where relationships between clients and suppliers have traditionally been dominated by highly formalized tendering processes and national regulation, the patterns of

10. For the views of a senior executive of a US firm, see Howard Shirmer, Jr., "Global Expansion: A Growing Dilemma" Journal of Management in Engineering, Vol. 12, No. 5, p. 28-31.

11. The potential of new information and telecommunications technologies for increasing the tradability of services has been discussed in Karl P. Suuvant, International Transactions in Services (Boulder, Col.: Westview, 1986). See also Bruno Lanvin (ed.), Trading in a Ne'w World Order - The Impact of Telecommunications and Data Services on International Trade in Services (Boulder, Col.: Westview Press, 1993). For an empirical examination of the implications of tradability in a specific sector, see UNCTAD, The Tradability of Banking Servicer: Impact and Implications ST/CTC/168 Current Studies Series A, No. 27. (Genevi: United Nations. 1994). 
international division of labour and organizational structures can be expected to change only slowly. Given the primary concern in this paper with the assessment of the impacts of new technologies, the economic, political and legal factors will be considered first and foremost in relation to the changes associated with the diffusion of technology. This paper thus secks to identify the structural and organizational impacts of the application of new information technologies for the engineering consultancy sector, in particular the potential for IT-enabled production and delivery to increase the tradability of various engineering consultancy services. ${ }^{12}$

\section{Concepts of Delivery Modes and Organizational Change}

The changes affecting the engineering consultancy sector outlined above suggests two key issues for the assessment of IT-enabled delivery modes. One of these issues concerns how IT-enabled delivery changes the overall competitive advantages of international engineering consultancy firms, and specifically whether the competitive advantages traditionally associated with FDI are being transformed into new competitive advantages related to direct trade in services. As we shall discuss in more detail below, the conceptual framework developed in

12. A more extensive study of the impact and implications of tradability in engineering consultancy services is published in UNCTAD. The Tradabilit) of Consulting Services (Geneva: UNCTAD, 1998) 
relation to the analysis of business strategies adopted by transnational corporations and the motivation to undertake FDI abroad is especially pertinent for discussion of this issue. The second issue concerns the ways in which the new, IT-enabled modes of production and delivery of engineering design services will affect organizational structures and processes in the sector, for instance by providing opportunities for project groups to interact across borders and time zones. In order to fully exploit such possibilities, many firms will have to reengineer both internal and external aspects of management, for instance the division of work among various project units and offices, or the relationships to clients, contractors, or partners. The theoretical perspectives and concepts put forward in recent years under the rubric of "business process reengineering" (BPR) appears particularly relevant to this discussion. We shall therefort briefly outline the concepts proposed for understanding reengineering processes in relation to engineering design and construction industries, and the role of IT-induced changes in these processes.

The choice between the alternatives of delivery of services via direct trade or through foreign direct investment (FDI) has teen analyzed from a variety of theoretical perspectives, notably, the eclectic paradigm of international production proposed by John Dunning which identifies factors influencing the investment 
decisions of multinational enterprises. ${ }^{13}$ This approach is focused upon explaining the decision of service firms to engage in FI)I abroad - as a contrast to selling their services across borders. It models the FDI decision as a result of the exploitation of the firm's advantages in three areas: ownership advantages, locational advantages, and internalization advantages. An illustration of these three types of advantages with special reference to engineering consultancy is shown in Table 1.

Internalization advantages are generally based on the fact that transaction costs of delivery of services on overseas markets arc considerable, and they have caused multinational service firms to prefer to use the hierarchical route of exchange of intermediate services with local partners for provision of services abroad. The establishment of joint ventures between major international engineering consultancy firms and local partners has been promoted by the governments in some countries, and the participation of local engineering consultancy firms have also been a priority of some clients, particularly in the public sector. These demands encourage the establishment of consortia involving local and foreign consulting firms or contractors for the purpose of obtaining a contract for an international project. Such consortia are usually created on a short-term basis.

13. This conceptualization has been associated, in particular, with the research published by John Dunning. See, for example, John H. Dunning, The Globalization of Business (London and New York: Routledge, 1993. 
Table 1: Three Aspects of Competitiveness for Transnational Corporations in the Engineering Consultancy Industry.

\begin{tabular}{|c|c|c|}
\hline $\begin{array}{l}\text { Ownership } \\
\text { (competitive advantages) }\end{array}$ & $\begin{array}{l}\text { Location } \\
\text { (configuration } \\
\text { advantages) }\end{array}$ & $\begin{array}{l}\text { Internalization } \\
\text { (co-ordinating } \\
\text { advantages) }\end{array}$ \\
\hline $\begin{array}{l}\text { Experience in home } \\
\text { and other foreign markets } \\
\text { Economies of size and } \\
\text { specialization } \\
\text { Economies of scope or } \\
\text { co-ordination }\end{array}$ & $\begin{array}{l}\text { Customization to local } \\
\text { tastes and need; } \\
\text { Need for on-the-spot } \\
\text { contact with customers } \\
\text { and related projucers }\end{array}$ & $\begin{array}{l}\text { Joint ventures to gain } \\
\text { local experience and } \\
\text { expertise } \\
\text { — Quality control } \\
\text { - Knowledge often very } \\
\text { idiosyncratic and tacit }\end{array}$ \\
\hline
\end{tabular}

Source: Based on Table 10.5 in John H. Dunning, The Globalization of Business (London and New York: Routledge, 1993), p. 272.

Because of the transitory nature of commitments to a national market that characterizes most projects undertaken by engineering design firms abroad, a significant preference exist among these firms to set up project offices rather than invest in local affiliates. The services provided in the fields of civil engineering, oil and chemical industry are, in particular, protie to take the form of turn-key 
projects. Only the largest transnational firm: in these industries are likely to have permanent offices in the countries they serve, and investment in the establishment of a full-fledged affiliate office usually only take place in countries that provide access to large domestic or regional markets for engineering consultancy services.

The locational advantages are particularly s:gnificant for a decision to establish local representation in the countries where they are delivering services. The vast majority of projects require some form of customization, and the need for on-thespot contacts with clients has traditionally imposed significant requirements of local presence. Experience in the UK has shown, for example, that engineering consultancy firms considered proximity to clients to be among the most important considerations for deciding to invest in affiliates abroad. ${ }^{14}$ Moreover, most engineering consultancy firms have developed their business strategies on the basis of long-term relationships with a limited range of clients. Local offices are one of the primary means for maintaining such relittionships and ensure a steady flow of new contracts. Professional partnerships appear to be the most widespread form of entering foreign markets. However, licensing on the basis of core knowledge and technology also take place to a limited extent. 
For the majority of engineering consultants, the ownership advantages that are specific to the firm relate to the accumulation of knowledge. The knowledge assets of such firms are manifested in the standards of quality requirements and reliability associated with the qualifications and training of personnel. Moreover, the specific competence that has been acquired through experience in other projects is frequently embodied in managerial competence or advanced tools. They constitute a major advantage for transnational engineering consultancy firms that increase their ability to access foreign markets. These are also advantages that are very difficult to keep within a proprietary realm in market-based transactions, however, and this is the reason that many firms seek to establish a local presence through setting up of local offices or the establishment of alliances with local firms.

The importance of specialized competence has induced many engineering consultancy firms to offer a relatively narrow range of products upon which they build their reputation and market shares. Sone firms are active in several specialized markets for engineering services such as building construction, petroleum, and environmental senvices, but the majority of firms seek to market services on the basis of in-depth specialized knowledge in one or several

14. See Table 9 in John H. Dunning, Tramsnational Corporations and the Growth of Services: Some Conceptual and Theoretical listes (UNCTC Current Studies, Series A, No. 9, ST/CTC/Ser.A/9) (New York: United Nations March 1989), p. 4.4. 
interrelated fields. Economies of size and specialization remain crucial to the engineering consultancy firms operating overseas, and FDI has been the dominant mode of exploiting these competitive advant iges.

The use of new, advanced information technology is likely become one of the key factors affecting the pattern of international delivery of engineering consultancy services. Conceptually, the impact of IT will be assumed to occur in different ways for various service products. For instance, a high potential for IT-enabled delivery would increase competitive pressure with regard to the services that can be potentially delivered at distance with minimal local presence (FDI or relocated personnel). On the other hand, IT enabled production processes may enhance the co-ordination of activities related to design with activities of construction, and among project participants. which would leild to greater integration of organizational structure and/or work processes, favouring consortia with boarder competence or large design-construction firms. All other things being equal, such a trend could raise barriers of entry for international engineering consultancy firms and strengthen existing oligopolistic marke structures. In other words, the differentiated impacts on the sector may lead to more competitive pressures in some markets and types of engineering design work, and encourage co-operation and mergers in other. 
The concept of business process reengineering has been launched to describe the transition from management in traditional functional organizations to new forms of business processes redesigned to gain significant improvements in performance. ${ }^{15}$ According to Peppard and Rowland:

BPR is an improvement philosophy. It aims to achieve step improvements in performance by redesigning the processes through which an organization operates, maximizing their value-added content and minimizing everything else. This approach can be applied at an individual process level or to the whole organization. ${ }^{16}$

Some authors have emphasized that BPR can be a valuable management tool regardless of whether the approach is used in conjunction with the introduction of new information technology. Nevertheless, many of the new processes that have been held forth as successful BPR achievements (e.g. the reengineering of the accounts payable department at the Ford Motor Company) have been based on processes facilitated by computer networks. ${ }^{17}$ Because information is increasingly recognized as a "factor of production", and given the enormous significance of

\footnotetext{
${ }^{15}$ The concept of Business Process Reengineering has a wide range of intellectual and practical origins, including socio-technical systems anilysis and total quality control programs, but its most conspicuous appearance was certainly associated with the work of Michael Hammer. See, e.g., Michael Hammer and James Champy. Reengincering the Corpuration: A Manifesto for Business Revolution New York: McGraw-Hill, 1993)

${ }^{26}$ See Joe Peppard and Philip Rowland. The Essence of Business Process Re-engineering New York: Prentice Hall, 1995), p. 20.
} 
knowledge and information in the production and delivery of consultancy services, it is obvious that business process reengineering will involve information technology in the engineering consultancy industry. What appears to be particularly important to the proponents of BPR is, however, that IT is not merely used for minor improvements of existing workflow, but for developing entirely new workflow processes and possibly even new products that will generate great leaps forward in quality and efficiency.

The use of IT as an enabling mechanism in relation to BPR has frequently been discussed in terms of the Venkataraman model. ${ }^{18}$ In this model, three different levels of business transformation related to the exploitation of IT are conceptualized. The first two levels of "localization exploitation" and "internal integration" represents evolutionary approach of employment of IT applications leading to discrete automation of existing processes and the integration of these in an IT-based infrastructure, respectively - but the third stage involves IT-enabled redesign or redefinition of the firm's business, thus representing a revolutionary approach (i.e., a true BPR effort) to business transformation.

\footnotetext{
${ }^{17}$ A collection of papers addressing various issues of reengineering with a strong influence from the perspective of IT applications is Jim Browne and David O'Sullivan (eds.). Re-engineering the Enterprise(London: Chapman \& Hall, 1995)
} 
Figure 1: Levels of IT-induced Business Reconfiguration

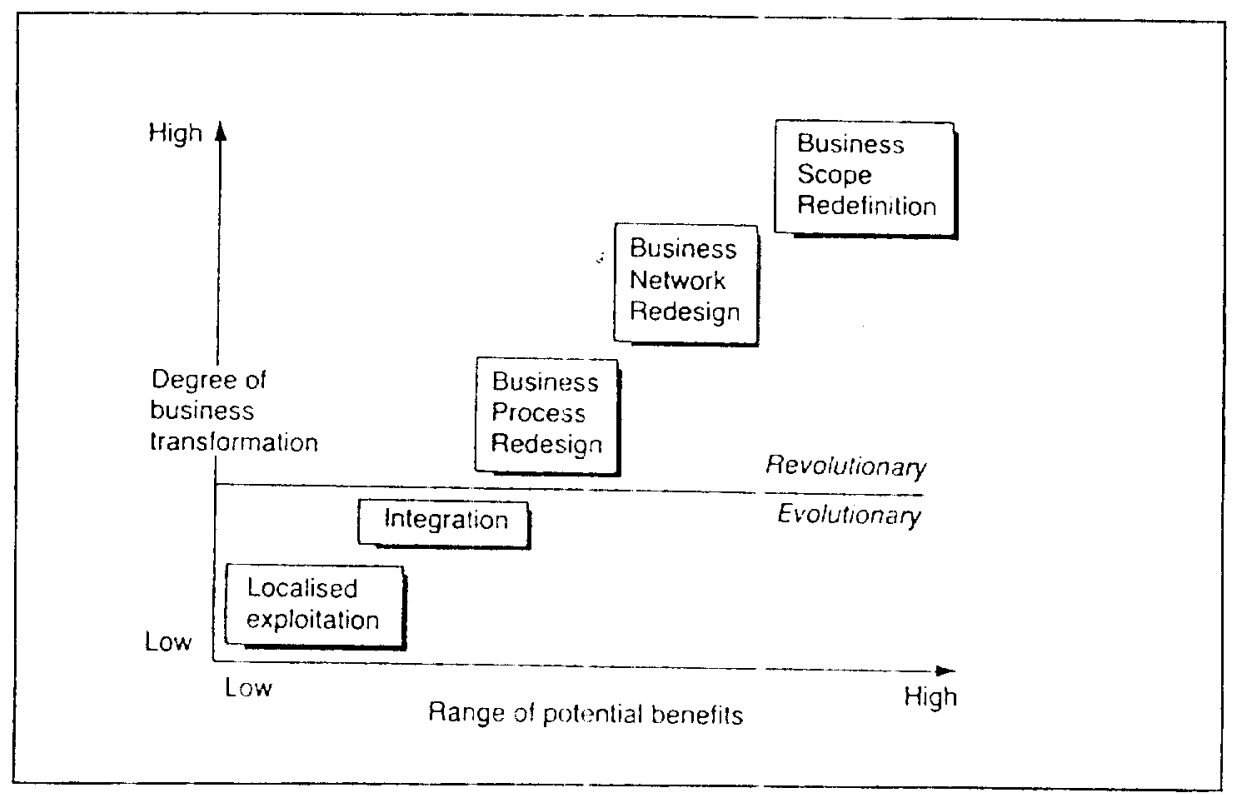

Source: Michel S. Scott Morton (ed.). The Corporation of the 1990's: Information

Technology and Organizational Transformation (Oxford: Oxford University Press, 1991)

Figure 1 shows the model in terms of progression of various uses of IT along a curve of increasing degree of business transformation. exploiting potential benefits of information and communications technology. The critical benefits are, in the conceptualization of this model, reaped when business process redesign moves

\footnotetext{
${ }^{10}$ See N. Venkataraman, "IT-induced business reconfiçuration" in Michel S. Scott Morton (ed.). The Corporation of the' 1990's: Information Technology and Organizational Transformation (Oxford: Oxford University P'ress, 1991)
} 
beyond the organization to include a wider network (e.g., clients, suppliers) to achieve greater efficiency in the total business performance. Finally, reaching the level of business scope redefinition implies a new awareness of the extent to which information and communications technologies can lead to completely new services and redefine ways of producing and delivering these services.

The most important impacts of IT-enabled delivery of engineering consultancy services are likely to be felt in the higher levels of redesign conceptualized in Venkataraman's model. For the construction industry, for instance, the model is useful to identify the threshold between evolutionary and revolutionary level of ITenabled business. ${ }^{19}$ Although the examples of BPR in the engineering design and construction service industries are very few there appears to be considerable scope for initiating processes of reengineering that would reduce construction cost and time and increase output quality, for instance by supporting closer relationships between key project participants. ${ }^{20}$ We shall return to a more detailed discussion of these changes below. Before turning to a discussion of the changes affecting the engineering consultancy sector arising out of various uses of information technology, however, it will be useful to present a concise overview of the structure and organization of the international engineering design consultancy

\footnotetext{
19 Denny McGeorge and Angela Palmer, Construction management: New Directions (Oxford: Blackwell Science, 1997), p. 136-139
} 
industry.

3. The Engineering Consultancy Service Sector: Structure, Organization, and Markets

Engineering consulting services as a specialized field of activity emerged during a later phase of industrial development, when a need for innovative solutions and improved design for construction projects and plant layout became apparent. The markets for engineering consultancy services are therefore primarily related to the growth of industries and construction, and business in the industry tends to fluctuate with cycles of growth and stagnation in manufacturing in major markets such as the US and Europe. Moreover, expansion or decline of public spending on infrastructure such as transportation or environmental facilities are also important for generating demand for engineering consuliancy products.

The engineering consultancy industry in the industrialized countries has typically consisted of a very large number of small firms, primarily serving a limited local market, and a rather small group of large firm; that were undertaking large projects at home and abroad. In the immediate post-war period, a single person or a

\footnotetext{
${ }^{20}$ See Sherif Mohamed and Selwyn Tucker, "Options for applying BPR in the Australian construction industry" International Joumal of Project Manageme u Vol 14, No. 6 (1996), pp. 379-385.
} 
partnership owned many such small engineering consultancy firms in the US, but during the 1970 s, a great number of these snall firms became incorporated. These have formed the backbone of a group of US design firms which continues to dominate the industry; many of the firms that were first surveyed by the ENR in 1965 are still listed high on the Top 500 list published today. ${ }^{21}$ During the $1990 \mathrm{~s}$ the level of concentration of ownership in the engineering consultancy industry increased further due to mergers and acquisitions. In the US, several major firms such as Raytheon Engineers \& Constructors have grown through acquisitions and reorganization, often creating a new spectrum of integrated services including aspects of construction. ${ }^{22}$ Growth and diversification has also been one of the key strategies in the expansion of the Parsons Corporation, which ranked no. 1 on the ENR list of the top 500 US design firms for $1994 .^{23}$ On the European scene, spates of mergers and acquisitions during the 1980 s have been motivated by the prospects for increased competition due to the Single European Market Act.

It may be difficult to distinguish analytically between the various components of the engineering consultancy sector, particularly because major contractors for

21. These firms include names such as Sverdrup, Louis Berger. Parsons, and Black \& Veatch. A number of other firms listed in 1965 have merged with other firms. Although new firms have entered the list and growing markets in sectors such as environmental services have raised some new firms to prominence; the continuity in this field is impressivt. See "Industry Stalwarts Still Practice", ENR April 3, 1995, p. 42.

22. See "Diversified Firms are Chomping at Market" ENR, April 5, 1993, p. 34-38; and "Economic Recovery Taking Hold But Too Late for 1993 Billings" ENR, April 4, 1994, p. 34-39. 
construction projects also provide design services and because there is a trend that "pure" engineering design consultancy firms are getting increasingly involved in the construction phase of major projects. The trend towards "design-build" coalitions is also affecting medium-sized and even smaller design firms, which are encouraged to enter into contracts related to design-build or construction management at-risk projects, often in consortiat including construction firms. In many cases, the demands from owners of projects are the driving forces leading engineering design firms to diversify into such areas. ${ }^{24}$ The private owners of major investment projects, in particular, appea to prefer to deal with "one-stop design supermarkets" rather than the traditional pattern of many different firms. The design-build concept is therefore becoming a key marketing tool for contractors as well as for engineering consultants. ${ }^{25}$ It has also been argued that computer networks can remove the traditional distinction between design and construction, a distinction which "...1s absolutely ridiculous. It's an artefact created by regulations. It's not a real reality."

The extent to which engineering design is purchased from specialized firms

23. "Competition, Government Cost Cuts Worry Desisners" ENR, April 3, 1995, p. 34-42.

24. An interesting investigation of the trends that have led to the popularity of the design-build concept in the US, and the consequences for both clients and engineering consultants is J.K. Yates, "Use of Design/Buikl in E/C Industry" Joumal of Manugement in Engineering Vol. 11, No. 6, p. 33-38.

${ }^{25}$ See William D. Booth. Design'Build Maketing: Strategie's for the Small and Mid-Size Contractors New York: Van Nontrand Reinhold, 1992. 
(independent consulting engineers typically organized in the Fédération

Internationale des Ingenieurs-Conseils, FIDIC), or is integrated in public or private firms (i.e. captive engineering design units in major contractor firms), is thus often a matter of national traditions. The tradition for integrated design departments in construction firms is, for instance, fairly strong in Italy and France. In these two European countries very few independent consulting engineers have been able to compete effectively. In Japan, the existence of a considerable domestic market for construction services has fostered an industry of contractors that are among the largest in the world, but only few of these occupy a significant position on the international design services market. ${ }^{27}$ Similarly, the independent Japanese engineering consultancy firms have not been able to become very competitive in international markets - in fact, their share o the market have declined from approximately 7 per cent in the $1980 \mathrm{~s}$ to 3 -4 per cent in $1990 \mathrm{~s}^{28}{ }^{2}$ In the UK and the US, there has been a much longer tradition for the use of independent consulting engineering firms. ${ }^{29}$ National traditions also tend to define various categories of

26. Statement by Paul Teicholz of Stanford Univer sity, quoted in "High-end networks come down to earth" ENR, June 7, 1993, p. 30

27. See Sidney M. Levy, Japan's Big Six. Case Studies of Japan's Largest Contraciors (New York: McGraw-Hill, 1993).

28. The ENR assessment of the international market in 1995 indicated that 13 Japanese firms captured 4.1 per cent of total international billing;; see "Designing Deals" ENR, Vol. 237, No. 4, (July 22), 1996. p. 37.

29. In the UK, engineering consultancy has often involved the supply of R\&D services, and outsourcing of such work to independent firms has t iken place to a larger extent than in the US. Some researchers have seen the increasing scope of internalization of $R \& D$ in major US manufacturing corporations as an important competitive advantage during the Twentieth Century, and the continued reliance on independent design firms among UK ma tufacturing corporations as a source of weakness in 
engineering design firms - such as the US-based categories of consulting engineer, engineering-constructor, architect-engineers, or the UK-based categories of architects, civil engineers, and quantity surveyors. In international markets, however, many categories of engineering desicn firms may compete with roughly similar services.

Perhaps due to these national traditions, firms from the US and Europe has occupied a dominant position in international markets for engineering consultancy. In 1985, for example, US firms supplied 32.0 per cent and firms from four European nations (Britain, France, (iermany, and Netherlands) 31.6 per cent of international engineering design services. In 1990, when the ENR survey included a number of large engineering-contractor firms, that had been left out in earlier surveys, the US share had gone up to 42 percent, while the four European nations still had a share equivalent to 32 per cent. In 1993, US and European shares were 42.5 per cent and 33.3 per cent respectively, and in $1995,42.6$ per cent and 40.6 per cent respectively. ${ }^{30}$ In other words, Americ an and European firms among the 200 largest engineering design firms included in the ENR surveys occupied more than 85 per cent of the international market, leaving a mere 11.7 per cent of the market to firms from Canada, Japan and other countries. 
The composition of the global market for engineering design is dominated by the industrial-petroleum sector, which constituted nearly 50 per cent of the foreign billings of US engineering consultancy firms in 1994. The foreign billings of transportation, building and power sectors constituted around $10-15$ per cent each, while international design work related to environmental services such as water supply, sewer/waste and hazardous waste (w hich by now is a major market in the US) only constitute some around 5 per cent each. There are various historical reasons for the differences in terms of internationalization of markets for engineering consultancy services in various sectors; for instance, high levels of internationalization of services in the petrolsum sector can be related to the exploitation of large oil reserves in developing countries in the Middle East and Latin America earlier in the Twentieth Century - where design firms followed the private oil companies (the so-called "Seven Sisters") abroad.

30. See: "Competitive Currents Tug Billings, ENR July 25, 1994, p. 22-24; and "Designing Deals" ENR July 22, 1996, p. 33-39. 


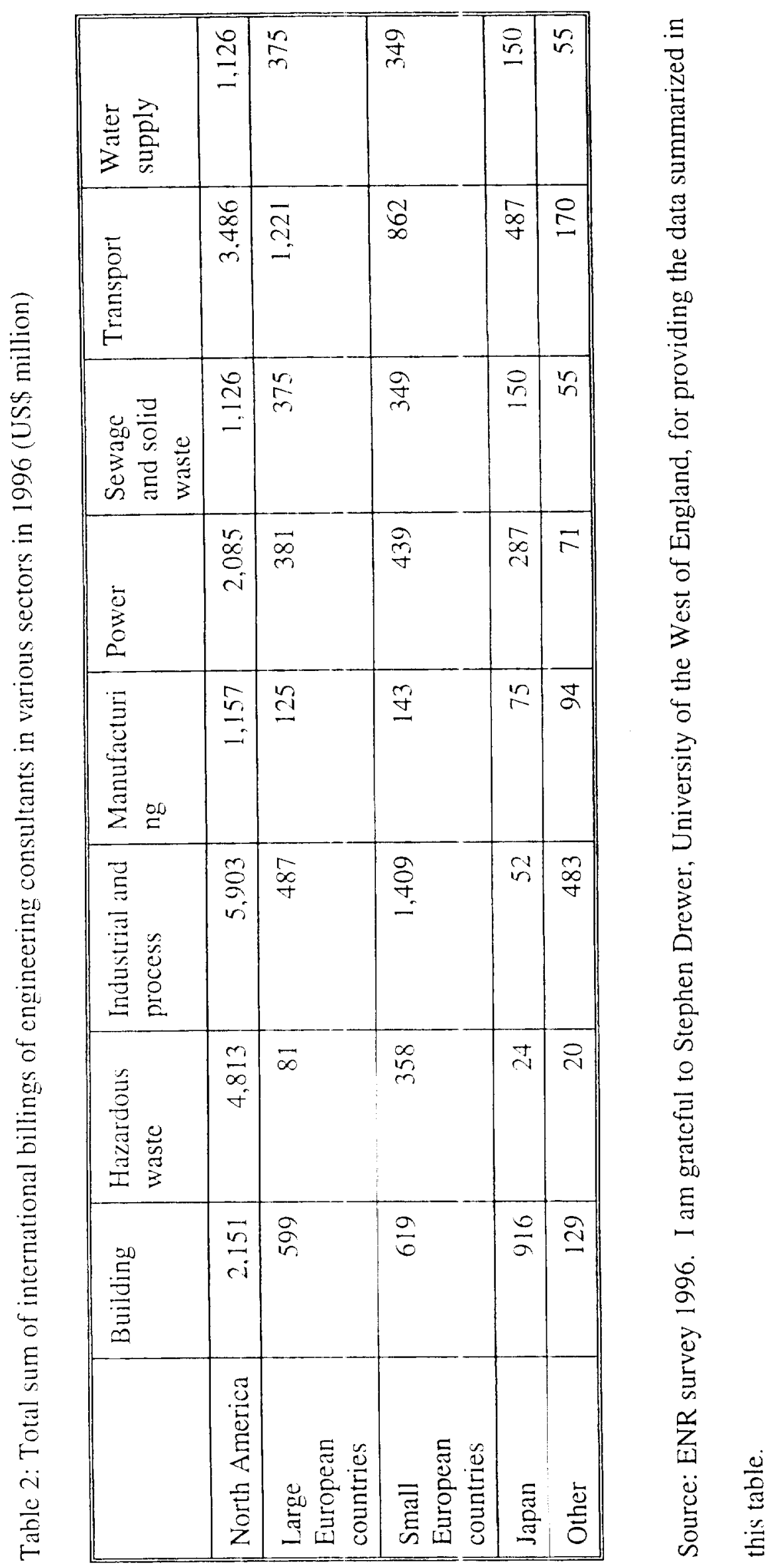


There is also a considerable degree of specialization among firms from various countries with respect to supplying engineering consultancy services to different types of markets. In particular, the data presented in Table 2 indicates that Japanese engineering consultants specialize primarily in markets for building design, a sector which also provides substantial revenues for European firms. The US engineering consultants are dominating international markets for industrial and process design (which includes the very important markets related to oil and petroleum industries); US firms are also doninant in hazardous waste. Large European nations, which includes large firms from the United Kingdom, maintain a sizeable market share in international markets for design in the transport sector, which is also an important market for firms from small European nations. It is also worth noting that small European nations have captured a significant share of the market for industrial and process design. Finally, the share accounted for by firms from other nations in this sector, almost hall a billion US dollars, is likely to be a reflection of the strength of one firm. Dar Al-Handasah Consultants, which has formally been based in Lebanon and Egypt. 
4. The Impact of Information Technology

The decade of the 1980 s witnessed a diffusion of computer-aided design (CAD) systems in the largest firms in the engineering consultancy sector in the US and Europe. Results of surveys conducted in three countries - United States, United Kingdom, and Sweden - and published in 1993 indicated that engineering consultancy firms in these countries were investing heavily in new information technology, and that information technology w as rapidly becoming an indispensable component of international competitiveness in the industry. The surveys were able to identify various benefits that the firms had derived from their investments in information technology but overall, the results of the application of information technology were observed in qualıtative changes rather than in financial returns. In other words. cost savings were not apparent even if information technology had already reduced the costs of producing technical drawings.

The effects of these investments during the 1930 s were thus most visible in relation to the employment of draughtsmen. While employment for other groups such as engineers and architects in US enginecring consulting firms increased by 20 per cent and 40 per cent respectively durin $1985-90$, employment of 
draughtsmen actually declined by 8 per cent. ${ }^{31}$ In other words, the introduction of new information technologies coincided with higher levels of employment for the advanced skill categories - engineers and architects who were associated with conceptual design work - and a reduced reliance on more routine work in the technical departments. At the same time, the new technologies have altered the work content and skill requirements of core groups such as engineers, who are increasingly required to operate CAD systems.

A number of significant changes in the strategic orientation of information technology investments in the sector took place with the transition to the 1990s. First. while information technology investments in the 1980 s were aimed at cost reductions (e.g., reducing the number of draughtsmen), investments in the $1990 \mathrm{~s}$ have sought to introduce interlinked local systems and to exploit more advanced capabilities of software applications. In other words, the use of advanced informaton technology in professional business tended to move from the first, localized exploitation, level to the second level of internal integration depicted in the model discussed above. Secondly, relatively simple and widespread facilities such as copiers and fax machines became common in nearly all sizes of engineering consultancy firms in the 1980 s while personal computers and

31. See UNCTAD, Information Technology anl International Competitiveness (op.cit.), p. 90 
workstations became ubiquitous, and gradually indispensable, in the operations of engineering consultancy firms during the 1990s. Thirdly, the integration of systems relying on computer-based technologies in the offices of large firms with advanced telecommunication networks have become the focus of the next, strategic phase of the utilization of information technology in the sector. In many ways, this move towards integration of IT-applications has signalled the coming of a period of business process reengineering and redefinition of business scope that is conceptualized as the advanced, revolutional level of business transformation in the Venkataraman model.

Emperical evidence for these various levels of business transformation associated with the use of information technology has been presented in a 1994 study of six large architecture and engineering design firms in the US. This study documented that work processes have been transformed from mostly manual activities using traditional enginecring tools to that of an electronic office environment using software applications and other advanced information technologies. Prior to the widespread use of CAD workstations, personal conpulers and other computerbased information devices, the work processes for designers, architects, and engineers in design firms revolved around the drafting table. Informal group discussions were conducted daily as an on-going process in order to accomplish engineering designs. With the advent of advanced information technology, the 
work process is different in that architects, designers, and engineers communicate through networks by transferring files or sharing common design files with overlay capabilities. The traditional comnunication forums achieved through team reviews and spontaneous meetings have diminished in importance. ${ }^{32}$

The main bottlenecks for a comprehensive strategy to use information technology in engineering consultancy firms were seen to relate to the cost of these new investments, the relative lack of operational skills among the staff, and the lack of appropriate software and standards for dat interchange. The US firms researched indicated that the information component of organizations had become largely computer based. Information had become more voluminous and available in more types of media and information formats, and this has produced mixed blessings for the engineering design firms. Design information can be created, transmitted, and stored at electronic speeds, but the lack of and adherence to proper information archive and retrieval procedures often results in sub-optimal re-use of design information, largely due to the difficulty of relocating, retrieving, and restoring this information from project archives. Therefore, the firms that had a pro-active program of information technology applicitions appeared to have a strategic advantage compared to those firms that acquired and utilized advanced

32. See McDonald Davis, III. The Impact of Ads anced Information Technologies on Architecture and Engineering Design Firms: A Ficld Study, (Unpublished PhD thesis, Virginia Commonwealth 
information technologies on an ad hoc project basis. It was concluded that a reengineering of the firm in terms of delivering the best value to the firm's client was warranted. Too many legacy systems, a general lack of information standards and protocols for dissemination of information, and a lack of concern for long-term technology programs were all contributing to the sub-optimal use of advanced information technologies.

Similar empirical data were presented in a survey of the use of computers in design and contractor firms in the US, carried out by the ENR in 1997, indicated that "slowly, but surely, the magnitude of information technology's impact on business practices is sinking in. ${ }^{133}$ Budgets for acquisition and application of information technology among design firms had been steadily growing for the period 19941997. Large design firms (with over $\$ 20$ millic $n$ in annual revenue) were spending an average of $\$ 856,900$ in 1994 and $\$ 1,364,000$ on information technology in 1997. Mid-sized design firms (\$5-20 million annual revenue) had almost tripled their average expenditure on information techrology, from an average of $\$ 189,600$ in 1994 to $\$ 575,500$ in 1997 . Budgets for information technology among small design firms had also increased, but at a slower pace. Large general contractors (with over $\$ 50$ million in annual revenue) wers spending an average of $\$ 1,031,200$

University, December 1994), p. 92.

33. See "Digital Demands" ENR Vol. 238, No. 12 (March 24). 1997, p. 30-36. 
in 1994 and $\$ 1,422,700$ in 1997 , but investments in information technology among other groups of contractor firms were relatively insignificant. The survey also indicated that almost half of both design firms and contractors planned to increase their spending on information technology in 1998.

For the majority of the firms, a major problem was to keep current with new generations of hardware, and in particular, software innovations. They also reported facing a major challenge in getting machines and software installed to work together in local networks or wide-area networks, and to integrate work processing with a view to exploiting the possibilities offered for linking design offices, contractors and project owners. The Internet promises to open new opportunities for interconnection, but many of the technical possibilities are as yet unexplored because much of the CAD software currently in use in the firms does not yet function effortlessly with internet browsers, and because the effective utilization of the new opportunities to interconnect requires a transformation of work patterns and attitudes among enginee s.

By the mid-1990s, the diffusion of information technology in the industry had thus reached levels where stand-alone applications were increasingly being integrated. The role of communications was now such that the possibilities for exchanging 
data between offices, or between designers and contractors, provide a basis for inter-operability. With these abilities, a future competitive advantage may be to offer delivery of data that is fully compatible with the needs and software of the client and/or the contractor. At the same time, the capabilities of CAD systems have changed in significant ways, to be able to handle data from maps, surveys and other sources in both two-dimensional and three-dimensional perspectives. ${ }^{35}$ They have also become more user-friendly and may be utilized in a variety of new ways to visualize the project and canying out checks of the quality and consistency of the design.

One of the key areas of impact by new information technologies has been in relation to decision making systems in engineering consultancy and construction firms. A study of trends in major US firms indicated that emerging construction processes utilizing decision support systems based on advanced information technology were quite different in character from conventional approaches. ${ }^{36}$ Thus, for example: (a) they bring fundamental changes to the timing, sequencing and hierarchy of decision making; (b) they aim to provide assurance that decision are based upon a common set of data; (c) they facilitate a new notion of client/use

34. See "Connectivity Key to Productivity" ENR July 1, 1996. p. 8-9.

35. For an overview of these trends see "The Next Dimension" ENR, June 17, 1996, p. 24-28. 36. See David Gann et al., Information Technology Decision Support in the Construction Industry: Current Development and Use in the L'nited States (Brighton: Science Policy Research Unit, September 1996), p. 9-15 
involvement in the total construction process; (d) implicit and explicit assumptions about design processes and their relationship, with production are transformed.

The technical innovations which support such new approaches rely on two interrelated developments: new enabling technologies, such as establishment of single project databases and the use of the Internet, and new applications technologies, such as object oriented software for engineering design and construction purposes. Both developments supported the integration of design and construction; in many respects, the new competitive strength of major engineering construction/contractor firms and the increased popularity of design-build or buildoperate-transfer arrangements in recent years provides evidence of the new role of integration.

The fact that much of the graphic, numeric and text-based information related to engineering design and construction managzment is currently stored in electronic form has meant that direct electronic delivery of these data to the client has become feasible. ${ }^{37}$ It is possible, for instance, for an engineering consultant to set

37. One indicator of the increased reliance on delivery of electronic data to the engineering consultants' clients is the appearance of new standards governing contracts involving such delivery. In Denmark, for example, Bygge- og Boligstyrelsen [The Administration of Buildings and Housing] at the Ministry of Housing has issued a report entitled Aflevering a digitule projektdata - Ansvars-og aftaleforhold [Delivery of Digital Project Data - Conditions for Liability and Agreement], May 1995. This report emphasizes that for the purpose of the legal assessment of liability etc., paper-based documentation should still be relied upon in the delivery of project data from engineering consultants. 
up an agreement with the contractor for a projert that the results of design are transferred from the computers of the consultant directly to the computer system of the contractor, thereby eliminating the re-entry of data such as specifications of components and materials, etc. Delivery of the product would usually, in such cases, comprise a copy of the project database (including many layers of data in different forms: graphic, numeric and text) with paper-based documentation of drawings, specifications related to the structure and contents of the database. The client, whether the contractor or the owner of the project, may already be using a specific system for management and implementation of projects, and would then require that the database delivered conforms to the format and specifications of this system. occasionally implying a translation of the data to the format required by the client.

Electronic delivery is often considered more resource demanding for the engineering consultant because the modifications required integrating the project database in the client's system involves additional time and occasionally procurement of new hardware or software. In aldition, this form of delivery raises special issues related to control of the extent to which the product fulfils the requirements specified in the contract, the responsibilities for errors in the material projects. Therefore, these actors ought to formulate an agreement concerning the data to be delivered and relevant standards (e.g., EDI standards) for data and software. 
(or errors that occur when the project database is integrated in the client's system), and the time that the product is delivered in a formal sense. These technical problems notwithstanding, however, the new information technologies promise to further promote trends towards new and stronger forms of networking between engineering consultants, contractors and the ir clients. ${ }^{38}$

Video-conferencing is another trend in the use of advanced information technology that is rapidly becoming essential in the interaction with clients overseas. ${ }^{39}$ The video-conferencing systems that have been used experimentally during recent years allow designers located in different offices to meet and discuss design simultaneously, using video cameras to capture images of the people participating in the meeting and integrating these with interactive work on a design from workstations in each location. The ability to interact more directly on the design from several locations has made video-conterences an important complement to project meetings, where the staff of the consultant or the client undertakes

\footnotetext{
38. For an interesting study of the entergence of rew networking patterns and partnerships among contractors and clients, see $\mathrm{H}$. Robertson et al. "The development of networks between engineering contractors and their clients: the special case of partnering" R\&D Management, Vol. 26, no. 4 (1996), p. $371-379$.

39. The US engineering consultanc: firm Day \& Zimmermann were among the pioneers in using video-conferencing systems in connection with a project to design a pharmaceutical plant in Zurich. Switzerland. "The owner was sceptical at first that much of the design work would be performed here in Philadelphia," says Ron Rothrock, senior vice president at D\&Z. But D\&Z set up a video-conferencing system where teams in Philadelphia and Zurich hold daily sessions to review CAD design changes in real time. "Once the system is set up, it s cheaper than commuting," Rothrock says". See ENR, April 3, 1995
} 
expensive international travel in order to meet in one physical location. Currently, there are still technical and economic limitations to the widespread use of videoconferencing systems, since these require very advanced and expensive hardware, software, and access to high-speed communicalion systems. There seems to be little doubt. however, that various forms of vide-o-conferencing systems will be gradually integrated in the work of engineering consultants in the foreseeable future.

An analysis of IT-enabled delivery for the products offered by engineering consultants indicates that there are quite a few products in the life cycle of engineering projects that can potentially be delivered via computer and telecommunications networks. ${ }^{40}$ Such IT-enabled delivery can take place both within and across national borders, once the nevessary technical infrastructure is available. The potential for IT-enabled delivery of various engineering consultancy services as part of the project cycle has been su nmarized in Table 3 .

40. The details of the analysis are published in UNCTAD. The Tradability of Consulting Services (op.cit.) 
Table 3: Summary of Prospects for IT-enabled Delivery for Engineering Service Products

\begin{tabular}{|c|c|c|}
\hline $\begin{array}{l}\text { Engineering service } \\
\text { product }\end{array}$ & $\begin{array}{l}\text { Technical } \\
\text { potential for } \\
\text { IT-enabled } \\
\text { delivery }\end{array}$ & Barriers to exploiting the potential \\
\hline $\begin{array}{l}\text { Identification and Pre- } \\
\text { feasibility }\end{array}$ & Poor & $\begin{array}{l}\text { Detailed knowledge of local conditions } \\
\text { required; need to work closely with cli- } \\
\text { ent }\end{array}$ \\
\hline Appraisal studies & Good & Work requires confidentiality \\
\hline Feasibility studies & Good & $\begin{array}{l}\text { Need for extensive experience; some } \\
\text { demand for knowledge of local } \\
\text { conditions }\end{array}$ \\
\hline Basic Design & Mostly good & $\begin{array}{l}\text { Depends on specialized skills; some } \\
\text { knowledge of local conditions required }\end{array}$ \\
\hline Detailed Design & Good & $\begin{array}{l}\text { Management of large project teams } \\
\text { requires co-ordination capabilities }\end{array}$ \\
\hline Supervision & Poor & Local physical presence required \\
\hline $\begin{array}{l}\text { Construction and } \\
\text { procurement } \\
\text { management }\end{array}$ & Mostly poor & Local physical presence required \\
\hline $\begin{array}{l}\text { Operation and } \\
\text { maintenance }\end{array}$ & $\begin{array}{l}\text { Poor } \\
\text { (for thaining: } \\
\text { good }\end{array}$ & $\begin{array}{l}\text { Physical presence required (not for } \\
\text { training) }\end{array}$ \\
\hline Rehabilitation & Mostly poor & Local data collection \\
\hline $\begin{array}{l}\text { Decommissioning and } \\
\text { removal }\end{array}$ & Poor & $\begin{array}{l}\text { Demand for local presence and } \\
\text { knowledge }\end{array}$ \\
\hline
\end{tabular}


The assessment of tradability for these products indicates a potential for some products, but it must be emphasized that exploitation of the technical possibilities for IT-enabled delivery has remained elusive. This is due primarily to requirements for knowledge about local conditions or the physical presence of the consultant at the site; issues of confidence and trust between consultants and project owners are also influencing the actual feasibility of IT-enabled delivery. The visit by consultants to the project site and the offices of the client will continue to be an important component of engineering consultancy projects. The activities most likely to be affected by IT-enabled production and delivery are "core" engineering design services such as feasibility studies and cletailed design; those that continue to depend on local presence are products associated with the phase of construction and implementation.

One implication of this would be that firms which specialize in design would be able to extend their markets on the basis of a higher competitiveness derived from centralized project execution, saving costs related to the movement of human resources. On the other hand, competitive pressure in the "footloose" design phases of the project cycle may be offset by competitive advantages in construction management, thus providing new advantages to firms with the ability 
to integrate design and construction management. The most likely scenario for the future would therefore be a combination of higher levels of competition in provision of design services and a pressure to integrate with closely related services such as construction and operation of projects.

4. Cross-Border Trade and Foreign Direct Investment: Substitute or Complementary?

The IT-enabled delivery of engineering consultancy services may, all other things being equal, enhance the tradability of products, and therefore be expected to facilitate cross-border trade over FDI. So far, however, the ratio between revenue from FDI and billings in direct exports to the countries served by engineering consultants does not yet appear to have undergone a significant change. Data relevant to examining this balance between FDI and trade, as modes of delivery, are scarce, however. One of the few sources available is published by the U.S. Department of Commerce, which can be used to compile the ratio of foreign investment and direct trade in foreign earnings by US firms, see Table 4. 
Table 4: U.S. International Transactions in Engineering Services, 1985-94 (Mill. US dollars $)^{\mathrm{a}}$

\begin{tabular}{|c|c|c|c|c|c|c|}
\hline Year & Imports & $\begin{array}{l}\text { Sales by } \\
\text { Foreign } \\
\text { Affiliates In } \\
\text { The US }\end{array}$ & $\begin{array}{l}\text { Ratio: } \\
\text { Imports/Sales } \\
\text { By Foreign } \\
\text { Affiliates In } \\
\text { US }\end{array}$ & Exports & $\begin{array}{l}\text { Sales By } \\
\text { US } \\
\text { Affiliates } \\
\text { Abroad }\end{array}$ & $\begin{array}{l}\text { Ratio: } \\
\text { Exports/Sal } \\
\text { es By US } \\
\text { Affiliates } \\
\text { Abroad }\end{array}$ \\
\hline 1985 & 301 & 1,990 & $\overline{0.15}$ & 759 & 3,275 & 0.23 \\
\hline 1987 & 163 & $2,367^{\mathrm{a}}$ & 0.07 & 668 & 2,246 & 0.30 \\
\hline 1990 & 170 & 3,897 & 0.04 & 867 & 6,105 & 0.14 \\
\hline 1991 & 315 & 5,054 & 0.06 & 1,478 & 7,198 & 0.21 \\
\hline 1992 & 261 & 5,572 & $\overline{0.05}$ & 1,935 & 8,639 & 0.22 \\
\hline 1993 & 336 & $\bar{N} / \mathrm{A}$. & & 2,358 & 9,357 & 0.25 \\
\hline 1994 & 296 & $6, \overline{253}$ & 0.05 & 2,704 & N/A. & \\
\hline
\end{tabular}

${ }^{a}$ Includes construction, architectural and mining services.

Sources: U.S. Department of Commeree, Survey of Current Business September 1994, September 1995; Foreign Direct Investment in the United States; U.S. Direct Investment Abroad; Foreign Direct Investment in the United States, Benchmark Survey, various issues. 
The data indicate that the ratio of aggregate figures for income from exports to figures for direct sales by US affiliates abroad has remained fairly constant during the period 1985-1993, most years amounting to 0.20-0.25. In other words, U.S. firms via FDI and local affiliates still primarily deliver engineering design services overseas. Trade, as a mode of delivery of cngineering services abroad has not become more important for U.S. firms during the decade 1985-95. Supply of engincering consultancy services to the U.S. by foreign firms has witnessed a decline in the ratio from 0.15 in 1985 to 005 in 1994. Investment in the U.S. thus constitutes an increasingly important means of delivery to the U.S. market by overseas suppliers. These relatively constant ratios between trade and FDI in overseas sales of engineering consultancy services point up the fact that whether or not new information technologies are able to substitute delivery by means of FDI with cross-border trade, such a shift in mode of delivery has not yet shown up in national or international statistics. Instead, they seem to re-confirm the essentially complementary nature of the two modes of delivery."

41. A complementary nature is also suggested by aggregate figures for overseas trade for non-bank US service firms for the period 1986.93, cross-border exports growing from US\$ 77.4 billion in 1986 to US $\$ 174.2$ in 1993, while sales from majority owned affiliates of US firms grew from US $\$ 60.6$ billion to 143.1 billion during the same period. It should be noted, however, that cross-border transictions were the predominant mode in Asia and the pacific, while sales from US affiliates were more widely used in Canada and Europe. See Michiel A. Mann and Sylvia E. Bargas, "US 
IT-enabled delivery of intermediate products of engineering design might be expected to change the role of intra-firm trade in engineering consultancy services, making affiliates more dependent on services provided from parent firms. Most recently available statistics from the US indicate that such intra-firm trade still tends to be relatively insignificant, since affiliates of engineering design firms are inclined to function as independent offices serving the local market. Statistics for 1993 published for US firms in engineering anil architectural services indicate that sales of services from US parent firms to affiliates (amounting to 33 million dollars) represented less than one per cent of ircome from direct sale of services by these parent firms $(8,145$ million dollars in 1993). In contrast, sales of services from the affiliates to local markets in 1993 amounted to 8,022 million dollars, that is, a sum that is almost equivalent to the total income from direct sales of their US parent firms. ${ }^{a 2}$

The promotion of trade in services has been an important priority in Europe, but here again the statistical data available do not appear to indicate any significant rise in trade rather than FDI related to engineesing consultancy services. The internal market in the European Unıon ( $E U$ ) has not yet succeeded in generating International Sales and Purchases of Private Services" Survey of Current Business Vol. 75, No. 9 (September 1995), p. 68-75.

42. See U. S. Department of Commerce, Economics and Statistics Administration/Bureau of Economic Analysis, U.S. Direct Imestment Abroad. Operations of U.S. Parent Companies and Their 
more cross-border trade, despite efforts to liberalize procurement of engineering services via several EU directives. ${ }^{33}$ Up until 1994 European countries continued to exhibit major domestic demands for engineering consultancy which were primarily served domestic suppliers, while cvailable statistics reveal little evidence of an increase in intra-EU trade.

Table 5: Turnover of engineering consultancy services in the European Union (Million ECU)

\begin{tabular}{|c|c|c|c|}
\hline & 1991 & 1992 & 1993 \\
\hline Domestic market & 9.800 & 11.000 & 9.450 \\
\hline Intra-EU trade & 400 & 400 & 400 \\
\hline Exports & 3.600 & 3.500 & 3.300 \\
\hline Total turnover & 13.400 & 14.500 & 12.750 \\
\hline
\end{tabular}

Source: Panorama of EU Industry 95-96, Frussels: European Commission, 1997

Foreign Affiliates. Preliminary 1993 Estimates (Washington, D.C.: U.S. Government Printing Office, June 1995), tables II.O.1; II.E.4; II.H.6; and II.H.23. 
Only 3-4 per cent of engineering consultancy services is exported in direct crossborder trade between EU member states, as indicated in Table 5. This is not, however, a sign that EU firms in general show less propensity to pursue export markets, since the same countries together export some 30 per cent of their services to countries outside the Union. The UK and Italy were the only countries which reported significant exports within the European Union, and engineering consultancy firms of these two countries were also the most noticeable exporters of services, with overseas sales representing 49 per cent and 34 per cent of total turnover, respectively, in 1993. ${ }^{44}$ In most countries of the European Union, exports of engineering consultancy services constitute approximately one-fourth of the total turnover, and the majority of contracts for these exports are with international organizations.

43. For instance, The Directive on Services and The I lirective on the Award of Public Service Contract (92/50). The EU Directive Concerning Procurement in the Water, Energy, Transport and Telecommunications Sectors (EU 93/38) was also intended to raise the level of intra-EU competition. 44. Figures reflect the results of a survey of members of the European Federation of Engineering Consultancy Associations (EFCA), representing approximately 40 per cent of the industry in Europe. See Table $l$ in the section (24) on Engineering consultancy services Panorama of EU Industry 95-96, (Brussels: Europan Commission, 1996), p. 45. 


\section{Conclusions}

The discussion presented here has adressed the issue of whether IT-enabled production and delivery of engineering consultancy services would fundamentally change patterns of trade and investment, and whether they would present challenges for reengineering of business processes for firms in the sector. We have seen that many of the large, international firms already utilize information technology and more advanced telecommunication links in order to promote cooperation between various offices or project groups. With the assistance of such technologies, firms have been able to further exploit ownership advantages such as economies of scale and scope, enabling them to strengthen their position vis-à-vis local competitors. Ownership advantages have always been very important in defining the competitive position of a few major engineering consultants, which rely on their reputation and a pool of highly qualified labour. But the growth and integration of IT-based systems enable firms to deploy these resources in a more systematic and efficient manner over long distances.

The potential for IT-enabled production of core engineering services such as basic and detailed design has made it possible to out-source these components of engineering projects to low-cost office sites or even to external, low-cost suppliers. 
However, these possibilities do not appear to have been exploited to the full extent, although some large international projects show that new information networks are becoming essential to linking international consortia participants in design and construction services. Large US firms have also embarked on strategies to utilize low-cost labour with computer skills in developing countries such as India or The Philippines for undertaking components of detailed design. ${ }^{45}$ In other words, IT-enabled production patterns have been able to enhance the competitive advantages of co-ordination, including quality control by head offices and use of specialized expertise and human resources on a global scale. These modes of internalization of crucial knowledge assets and a more effective and efficient employment of these assets at an international scale constitutes a fundamental aspect of the competitiveness of major firms in the international markets for engineering consultancy services, and IT appeas to have strengthened the position of these firms glohally.

A more comprehensive shift towards IT-enabled delivery of engineering consultancy services can be envisaged to involve a transition of the pattern of internationalization in three aspects: 1) a move irom FDI to direct cross-border trade as a means of delivery abroad; 2 ) a reliance on capital-intensive components

45. According to an interview in May 1995. The Parsons Corp. in the US have established high-speed links to their affiliate in The Philippines, where local engineers are doing detailed design. 
of competitiveness by engineering consultants from industrialized countries in overseas markets; and 3) a new division of labour among participants in consortia for international engineering projects. The analysis presented here does yet reveal statistically significant linkages between the diffusion of IT and emerging globalization of engineering consultancy firms. But future research may reveal a more explicit tendency for international wo k to reflect the three above-mentioned trends. 